\title{
Operational use of neem oil as an alternative anopheline larvicide. Part A: laboratory and field efficacy
}

O.M. Awad ${ }^{1}$ and A. Shimaila ${ }^{1}$

$$
\begin{aligned}
& \text { الاستخدام الميداني لزيت النيم كبديل لمبيدات يرقات البعوض - الجزء الأول، النجاعة الميدانية } \\
& \text { والمختبرية الاستخام المبام } \\
& \text { أسامة عوض وعبد الله شيميلة } \\
& \text { الحلاصة: أجريت الدراسة لمعرفة مدى النجاعة الميدانية والمختبرية لزيت النيم في إبادة يرقات البعوض، و وم يلاحظظ }
\end{aligned}
$$

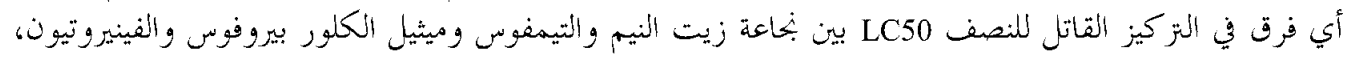

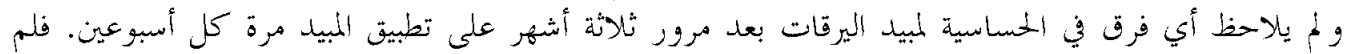

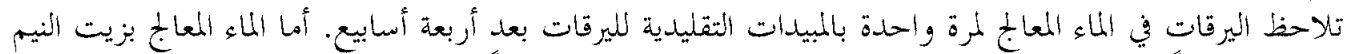

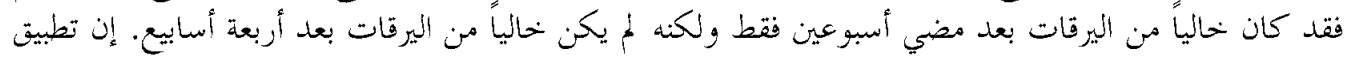

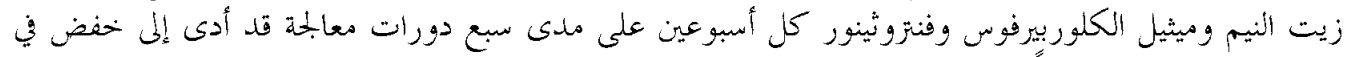

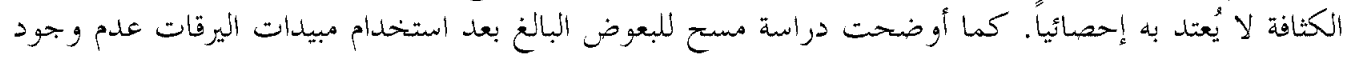

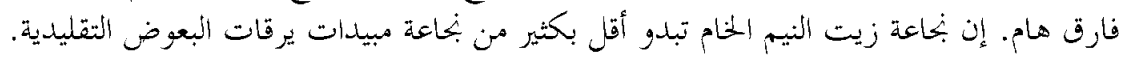

ABSTRACT We conducted a study to determine the laboratory and field efficacy of neem oil towards anopheline larvae. No difference in $\mathrm{LC}_{50}$ was observed between laboratory and field strains for temephos, chlorpyriphos-methyl/fenitrothion and neem oil. No difference in susceptibility was found after 3 months of application every 2 weeks. Water treated with a single application of traditional larvicides was free of larvae after 4 weeks; neem oil-treated water, however, was free after 2 weeks but not at 4 weeks. Application of chlorpyriphos-methyl/fenitrothion and neem oil every 2 weeks for 7 rounds resulted in dramatic reduction in larval density with no statistically significant differences. An adult survey after larviciding also showed no significant difference. The efficacy of crude neem oil appears to be below that of conventional larvicides.

Utilisation opérationnelle d'huile de margousier comme autre larvicide d'anophèle. Partie A : efficacité en laboratoire et sur le terrain

RESUME Nous avons réalisé une étude pour déterminer l'efficacité en laboratoire et sur le terrain de l'huile de margousier contre les larves d'anophèles. Aucune différence dans la CL50 n'a été observée entre les souches de laboratoire et de terrain pour le téméphos, le chlorpyrifos-méthyl/fénitrothion et l'huile de margousier. Aucune différence de sensibilité n'a été observée après 3 mois d'application toutes les 2 semaines. L'eau traitée avec une seule application de larvicides traditionnels ne contenait aucune larve au bout de 4 semaines ; par contre, l'eau traitée à l'huile de margousier était exempte de larves au bout de 2 semaines mais pas après 4 semaines. L'application de chlorpyrifos-méthyl/fénitrothion ou d'huile de margousier toutes les 2 semaines à 7 reprises a permis une réduction spectaculaire de la densité larvaire sans différence statistiquement significative. Une étude sur les adultes après utilisation de larvicides n'a pas non plus révélé de différence significative. L'efficacité de l'huile de margousier brute semble être inférieure à celle des larvicides classiques.

${ }^{1}$ Tropical Health Department, High Institute of Public Health, University of Alexandria, Alexandria, Egypt.

المجلة الصحية لشرق المتوسط، منظمة الصحة العالمية، المجلد التاسع، العدد ع، ب... 


\section{Introduction}

Malaria is one of the major public health challenges eroding development in the poorest countries in the world. The disease exerts its heaviest toll in Africa. Around $90 \%$ of the deaths from malaria worldwide (over 1 million each year) occur in subSaharan Africa [1]. Malaria has been recognized in Egypt since ancient times [2]. At present, Fayoum governorate is the only focus of malaria in the country [3]. In Sinnuris district of Fayoum governorate, 3 anopheline species are encountered, Anopheles sergenti, An. multicolor and An. pharoensis, the first being the most abundant $[4,5]$.

The UN General Assembly has designated 2001-2010 the decade to Roll Back Malaria in developing countries, particularly Africa. The Roll Back Malaria programme is a global partnership founded in 1998 by the World Health Organization (WHO), the United Nations Development Programme, the United Nations Children's Fund and the World Bank with the goal of halving the world's malaria burden by 2010 [1]. Vector control is still one of the WHO approaches for Roll Back Malaria technical strategies [1].

The principal objective of vector control is the reduction in morbidity and mortality due to malaria by reducing the level of transmission. When all possible elimination of water has been accomplished, larvae can then be controlled by the use of chemicals. The simplest chemicals for larviciding are fuel oil and/or kerosene. Various insecticide formulations can be used repeatedly as larvicides [6]. Taking environmental and economic concerns into consideration, botanical larvicides should be examined.

The neem tree (Azadirachta indica) is a tropical evergreen related to mahogany and has shown promising results as a pesticide in many areas. This species may be the forerunner of a new generation of "soft" pesticides that could be used in benign ways. Azadirachtin, one of the active principals of neem, has proven to be the tree's main agent for attacking insects. It appears to be responsible for about $90 \%$ of the effect on most pests [7]. It does not kill insects immediately, instead it repels them and disrupts their growth and reproduction. Neem products exhibit various modes of action against insects such as antifeedancy, growth regulation, suppression of fecundity, sterilization, oviposition repellency or attractancy, changes in biological fitness and blocking of the development of vector-borne pathogens. Although bioactive compounds are found throughout the tree, those in the seed kernels are the most concentrated and accessible (2-4 mg/g kernels) $[8,9]$.

The larvae of a number of mosquito species (including Aedes and Anopheles spp.) are sensitive to neem. The use of simple and cheap neem products seems promising for treating pools and ponds in the towns and villages of developing countries [10]. Various concentrations of neem oil $(1 \%-4 \%)$ in coconut oil or mustard oil when applied to exposed parts of the human body have been shown to provide protection from mosquito bites over a period of 12 hours [11]. Neem oil mixtures burned in a kerosene lamp in living rooms reduced biting of human volunteers and catches of Anopheles spp. [12]. Balls of wood scrapings soaked in $5 \%, 10 \%$ and $20 \%$ neem oil diluted in acetone controlled An. stephensi and Ae. aegypti breeding in overhead storage tanks for 45 days [13]. Application of $5 \%$ neem oil-water emulsion at $50 \mathrm{~mL} / \mathrm{m}^{2}$ in pools and at $100 \mathrm{~mL} / \mathrm{m}^{2}$ in tanks resulted in $100 \%$ reduction of third and fourth instar larvae [14]. Complete inhibition of oviposition has been observed by exposure of

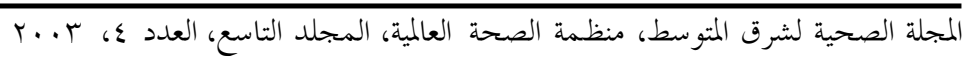


mosquitoes to neem oil and a fraction containing volatile components [15].

The objectives of our study were to determine the susceptibility of anopheline larvae towards neem oil in the laboratory and to evaluate its efficacy in the field compared with traditional compounds.

\section{Methods}

Two villages, El Henawy and Abheit El Hagar in Sinnuris district, Fayoum governorate, were selected for implementation of this study. They are $12 \mathrm{~km}$ and $7 \mathrm{~km}$ respectively away from Sinnuris town.

We tested neem oil and 2 other larvicides, temephos and chlorpyriphos-methyl/ fenitrothion. Neem oil was purchased commercially from Plasma Power Private Limited, Chennai, India. According to the provider, the azadirachtin content of the oil is $1570 \mathrm{ppm}$. Temephos, as Bordin EC for public health purposes (temephos 50\%, berol 11\%, emulsifiers and white kerosene 39\%, Reg. No. 647/2000), was purchased from the market. It is produced by Al Helb for Pesticides and Chemicals, New Domiat, Egypt. The chlorpyriphos-methyl/ fenitrothion was purchased as Chlorosol EC (chlorpyriphos-methyl 20\%, fenitrothion 20\%, emulsifiers and solvents 60\%). This is produced by Kafr El Zayat Company for Pesticides and Chemicals, Kafr El Zayat, Egypt.

After many trials, FEBA (dish washing material, produced by Alexandria Company for Chemicals and Detergents, Alexandria, Egypt) at a concentration of 1:5 (detergent: neem oil) was the most suitable detergent with respect to efficiency, reproducibility of results, toxicity to the environment and cost.

Susceptibility was established to emulsified neem oil and also to the emulsifying agent and a vegetable oil for comparison. Stock solutions of temephos and chlorpyriphos-methyl/fenitrothion were also prepared.

\section{Laboratory bioassay}

Anopheline larvae collected from the field were reared in the laboratory [16]. After 50 generations, this strain was considered a laboratory strain and the susceptibility tests to neem oil, temephos and Chlorosol were carried out in the laboratory for both laboratory and field strains [17]. We evaluated the susceptibility of field strains of anopheline larvae collected from El Henawy village to neem oil and anopheline larvae collected from Abheit El Hagar village to chlorpyriphos-methyl/fenitrothion after 3 months of application every 2 weeks [17].

Laboratory strains of anopheline larvae were selectively pressured against neem oil for 5 generations and susceptibility to neem oil was recorded [16].

\section{Field study}

To evaluate the efficacy of neem oil, temephos and chlorpyriphos-methyl/fenitrothion with regard to anopheline larvae in different water bodies, according to the preliminary survey, El Henawy village was divided into 4 similar sectors, each with 5 different water bodies, after exclusion of those water bodies which were highly polluted with household washing detergent. Larval density was determined pretreatment and 1, 2, 3, 7, 14 and 28 days post-treatment [17]. Three sectors were treated with 1 larvicide each at the following concentrations:

- Neem oil 2.5\% plus $0.5 \%$ detergent (250 mL neem oil plus $50 \mathrm{~mL}$ detergent for a $10 \mathrm{~L}$ back sprayer per $100 \mathrm{~m}^{2}$ ).

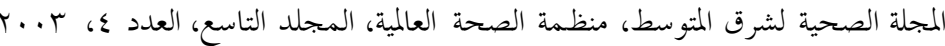


- Temephos at $35 \mathrm{~mL}$ for a $10 \mathrm{~L}$ back sprayer per $100 \mathrm{~m}^{2}$, as recommended by the Ministry of Health and Population.

- Chlorpyriphos-methyl/fenitrothion at $10 \mathrm{~mL}$ for a $10 \mathrm{~L}$ back sprayer per $100 \mathrm{~m}^{2}$, as recommended by the Ministry of Health and Population.

- The fourth sector was left untreated for the control study.

We carried out tests to study the field efficacy of the implementation of neem oil as an alternative larvicide in El Henawy and Abheit El Hagar. Each village was divided into 4 sectors; in each sector 6 water bodies were chosen. The water bodies in $\mathrm{El}$ Henawy were treated every 2 weeks with $5 \%$ neem oil emulsified with $1 \%$ dish washing detergent $(500 \mathrm{~mL}$ neem oil plus $100 \mathrm{~mL}$ detergent for a $10 \mathrm{~L}$ back sprayer per $100 \mathrm{~m}^{2}$ ). The water bodies in Abheit El Hagar were treated every 2 weeks with chlorpyriphos-methyl/fenitrothion at $10 \mathrm{~mL}$ for a $10 \mathrm{~L}$ back sprayer per $100 \mathrm{~m}^{2}$ according to the schedule of the Ministry of Health and Population. Larviciding was done every 2 weeks for 7 rounds (30 June21 September). Larval densities were monitored pre-application and every week post-application until the end of the schedule and 4 weeks subsequent (30 June-19 October) [16].

Adult mosquito densities were determined in parallel in order to study the impact of larviciding on adult density. In each village a group of 10 houses and group of 10 animal sheds were randomly selected. Mosquitoes were collected by the spray sheet collection method using $0.1 \%-0.2 \%$ pyrethroid solution in kerosene [16]. The collection of adult mosquitoes was carried out early in the morning between 06.30 and 10.00. The mosquitoes were collected into small, labelled boxes to be counted and identified according to the keys given by Story [18] and Gillies and DeMeillon [19].

\section{Results}

\section{Susceptibility of anopheline larvae towards traditional larvicides and neem oil in the laboratory}

The $\mathrm{LC}_{50}$ of neem oil for the laboratory and fields strains after 24 and 48 hours was almost the same (17.17-20.08 ppm). The $\mathrm{LC}_{50}$ for the laboratory and fields strains after 24 hours was $0.58 \mathrm{ppm}$ and $0.61 \mathrm{ppm}$ for temephos and $0.10 \mathrm{ppb}$ and $0.11 \mathrm{ppb}$ for chlorpyriphos-methyl/fenitrothion. Selective pressure with neem oil for 5 successive generations did not produce a resistant, tolerant strain or even change the susceptibility of the mosquito larvae to neem oil. Treatment of water bodies every 2 weeks for 3 months did not change the response of anopheline larvae towards such tested substances either.

\section{Field efficacy of traditional larvicides and neem oil towards anopheline larvae}

The mean anopheline density before treatment was between 347.0 and 112.7 larvae/ 100 dips. Four weeks after a single application of temephos or chlorpyriphos-methyl/ fenitrothion, treated water bodies were clear of any anopheline larvae. In contrast, water bodies treated with neem oil were clear of anopheline larvae until the second week after treatment, but presented a high larval density (647 larvae/100 dips) 4 weeks after treatment compared with the control water bodies which showed a mean of between 453 and 1127 larvae/100 dips throughout the observation period. Analysis of variance and least significant difference tests showed the difference between the control and the treated water bodies to be statistically significant $(P<0.01)$ (Table 1$)$.

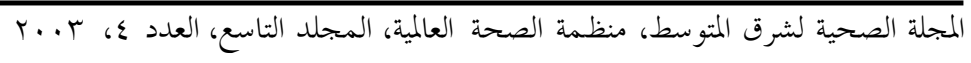


\begin{tabular}{lc}
\hline Eastern Mediterranean Health Journal, Vol. 9, No. 4, 2003 & $\mathbf{6 4 1}$
\end{tabular}

\begin{tabular}{|c|c|c|c|c|c|c|c|}
\hline \multirow[t]{2}{*}{ Larvicide } & \multicolumn{7}{|c|}{ No. of anopheline larvae per 100 dips } \\
\hline & $\begin{array}{c}\text { Pre- } \\
\text { application }\end{array}$ & 1 day & 2 days & $\begin{array}{l}\text { Post-ap } \\
3 \text { days }\end{array}$ & $\begin{array}{l}\text { plication } \\
1 \text { week }\end{array}$ & 2 weeks & 4 weeks \\
\hline \multicolumn{8}{|l|}{ Temephos } \\
\hline $\begin{array}{l}\text { Mean } \\
\text { Range }\end{array}$ & $\begin{array}{c}1127 \\
0-5000\end{array}$ & $0^{\star \star}$ & $0^{\star \star}$ & $0^{\star \star}$ & $0^{\star \star}$ & $0^{\star *}$ & $0^{\star *}$ \\
\hline $\begin{array}{c}\text { Chlorosol } \\
\text { Mean } \\
\text { Range }\end{array}$ & $\begin{array}{c}347 \\
67-833\end{array}$ & $0^{\star \star}$ & $0^{\star *}$ & $0^{\star *}$ & $0^{\star \star}$ & $0^{\star *}$ & $0^{\star *}$ \\
\hline $\begin{array}{c}\text { Neem oil } \\
\text { Mean } \\
\text { Range }\end{array}$ & $\begin{array}{c}747 \\
533-1533\end{array}$ & $0^{\star *}$ & $0^{* *}$ & $0^{\star \star}$ & $0^{* *}$ & $0^{\star *}$ & 647 \\
\hline $\begin{array}{c}\text { Control } \\
\text { Mean } \\
\text { Range }\end{array}$ & $\begin{array}{c}693 \\
0-1633\end{array}$ & $\begin{array}{c}1127 \\
100-4167\end{array}$ & $\begin{array}{c}453 \\
0-1200\end{array}$ & $\begin{array}{c}529 \\
0-833\end{array}$ & $\begin{array}{c}527 \\
0-1133\end{array}$ & $\begin{array}{c}498 \\
0-767\end{array}$ & $\begin{array}{c}1007 \\
600-1333\end{array}$ \\
\hline
\end{tabular}

aNumber of anopheline larvae per 100 dips.

**Significantly different from control $(\mathrm{P}>0.01)$, analysis of variance and least significant difference tests.

\section{Field efficacy of neem oil as an alternative anopheline larvicide}

For the 7 rounds of larvicide application, no anopheline larvae were detected 1 week after each application with either neem oil or chlorpyriphos-methyl/fenitrothion. However, throughout the application period, 2 weeks after every application between $8.33 \%$ and $66.67 \%$ of the water bodies tested were infested with anopheline larvae in both villages, with no statistically significant difference. The baseline mean anopheline larval density was 604 larvae/ 100 dips in El Henawy village (treated with neem oil) and 982 larvae/100 dips in Abheit El Hagar village (treated with chlorpyriphos-methyl/fenitrothion). After application of both substances, anopheline larval density declined to zero 1 week after each application. Two weeks after each application, mean larval density ranged from 3 to 172 larvae/100 dips. Univariate analysis indicat- ed that there was no significant difference between treatment with neem oil and treatment with chlorpyriphos-methyl/ fenitrothion $(F=0.029)$, however time/ date of treatment showed significant difference in larval density $(F=11.13)$ (Table 2).

The baseline data for anopheline adult infestation in the 2 villages in both dwellings and animal sheds showed that the infestation was between $0 \%$ and $13.8 \%$ of the observed sites in both villages. Throughout the larviciding period, the infestation rate ranged between $4.4 \%$ and $36.0 \%$ of dwellings and between $10.0 \%$ and $60.0 \%$ of animal sheds with no statistical difference between the 2 substances except 2 weeks after the last round of application of the larvicide (Z-test) (Table 3). The highest indoor resting density found was 2.75 in Abheit El Hagar. An. sergenti was the most abundant species then $A n$. multicolor; An. pharoensis was rare in both

المجلة الصحية لشرق المتوسط، منظمة الصحة العالمية، المجلد التاسع، العدد ؟، ب... 
Table 2 Anopheline larval density in water bodies after spraying with neem oil every 2 weeks $\left(500 \mathrm{~mL} / 10 \mathrm{~L}\right.$ per $\left.100 \mathrm{~m}^{2}\right)$ in El Henawy village and Chlorosol $(10 \mathrm{mLI} / 10 \mathrm{~L}$ per $100 \mathrm{~m}^{2}$ ) in Abheit El Hagar village

\begin{tabular}{lrcrc}
\hline $\begin{array}{l}\text { Date of } \\
\text { larviciding } \\
\text { (day/month) }\end{array}$ & \multicolumn{2}{c}{$\begin{array}{c}\text { Neem oil } \\
\text { No. of larvael } \\
\text { 100dips } \\
\text { Mean }\end{array}$} & \multicolumn{2}{c}{$\begin{array}{c}\text { Range } \\
\text { Ro. of larvael } \\
\text { 100dips }\end{array}$} \\
\hline $30 / 6$ & 604 & $189-1533$ & 992 & $428-1317$ \\
Mean & Range \\
$15 / 7$ & 69 & $0-222$ & 56 & $0-192$ \\
$28 / 7$ & 171 & $56-453$ & 26 & $0-106$ \\
$10 / 8$ & 22 & $0-45$ & 3 & $0-11$ \\
$24 / 8$ & 137 & $39-170$ & 78 & $6-197$ \\
$7 / 9$ & 20 & $0-64$ & 8 & $0-33$ \\
$21 / 9$ & 29 & $0-56$ & 29 & $0-83$ \\
$5 / 10^{a}$ & 61 & $11-94$ & 44 & $33-56$ \\
$19 / 10^{a}$ & 170 & $72-400$ & 124 & $0-195$ \\
\hline
\end{tabular}

${ }^{a}$ No larviciding done. Larviciding was done every 2 weeks from 30 June 2002 until 21 September 2002; larval survey was done just before every application.

villages. The difference in indoor resting density for female adult anophelines in the 2 villages was statistically significant in favour of the efficiency of neem oil larviciding (Table 3).

\section{Discussion}

Susceptibility of anopheline larvae
to temephos, chlorpyriphos-
methyl/fenitrothion or neem oil in
the laboratory susceptibility between the laboratory and field strains of anopheline larvae to all 3 substances. However, the toxicity of the pure crude neem oil extract towards the 2 strains was lower than that of the other 2 substances. Almost the same level of toxic- ity has previously been reported for temephos towards An. culicifacies larvae [20] and for chlorpyriphos and fenitrothion, the components of Chlorosol, towards some anopheline species [21].

As anticipated in a study period of only 3 months, the anopheline mosquitoes did not develop any kind of resistance to these larvicides. Additionally, the low number of generations selectively pressured as well as the complexity of the neem extracts and their different modes of action must be taken into account. Research has shown that it seems unlikely that any resistance to mixtures of neem products will develop in a short run. The build-up of resistance is much more likely with refined neem formulations based on a single active ingredient such as azadirachtin [10].

\section{Field efficacy of neem oil to control anopheline larvae in water bodies compared with traditional larvicides}

The larvicidal efficacy of a single application or scheduled multiple applications of neem oil, temephos and chlorpyriphosmethyl/fenitrothion on water body surfaces is reported in this study as anopheline larval density (Table 2) or adult density (Table 3) and no statistical differences were found.

Using the neem plant, either crude parts of the plant, pure oil, solvent extracts or neem-based industrially formulated insecticides, as an alternative mosquito larvicide has been shown to be efficient and is recommended by many studies. For example, application of $5 \%$ neem oil-water emulsion in mosquito breeding habitats at $50 \mathrm{~mL} / \mathrm{m}^{2}$ in pools and at $100 \mathrm{~mL} / \mathrm{m}^{2}$ in tanks resulted in $100 \%$ reduction numbers of third and fourth instar larvae of An. stephensi after 24 hours [14]. Similarly, application of $10 \%$ emulsion in desert coolers against $A e$. aegypti at $40-80 \mathrm{~mL}$ per cooler resulted in 


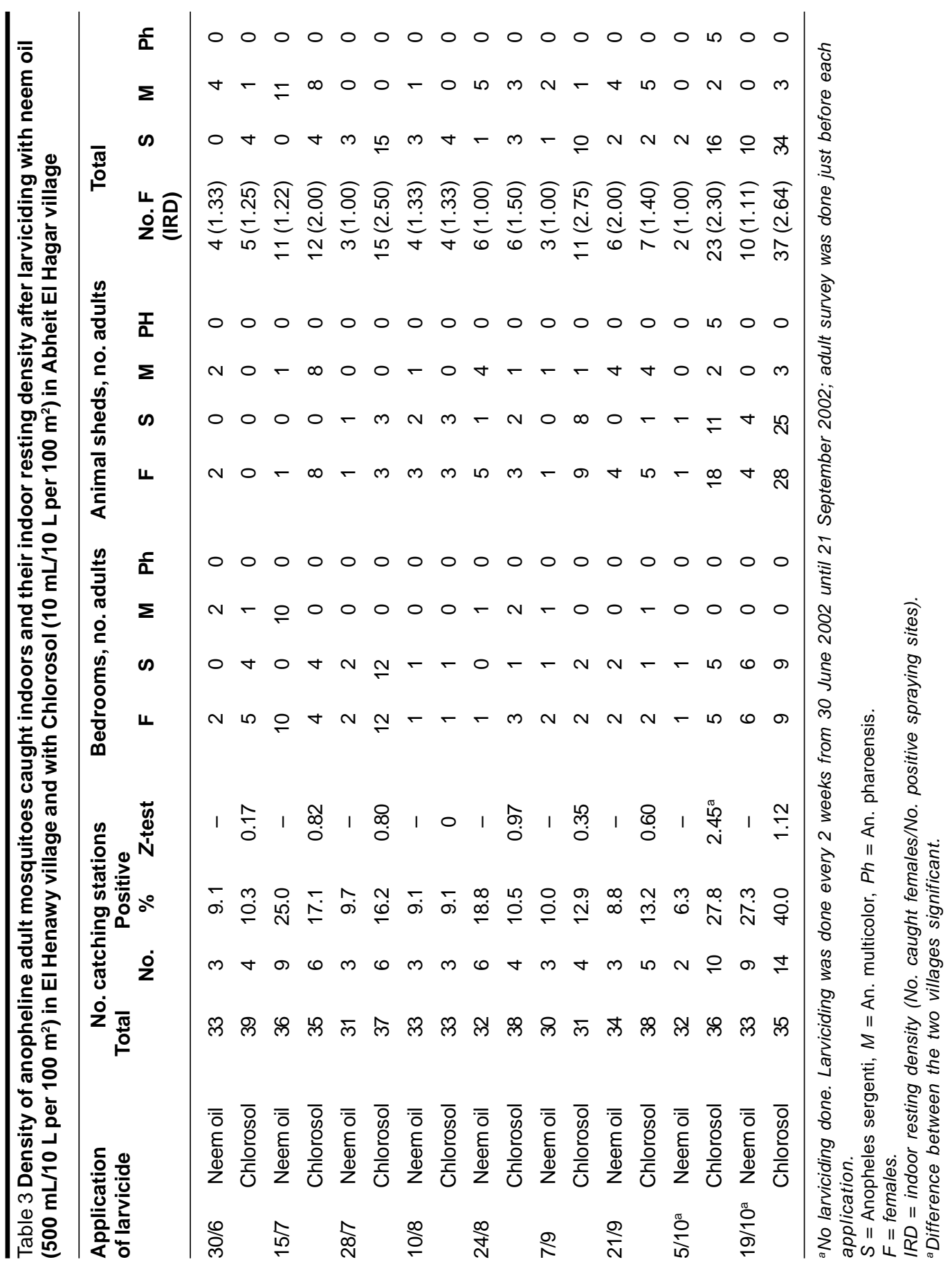

المجلة الصحية لشرق المتوسط، منظمة الصحة العالمية، المجلد التاسع، العدد ع، ب... 
complete inhibition of pupal production [14]. Also, pre-soaked wood scraping balls in $5 \%, 10 \%$ and $20 \%$ neem oil diluted in acetone controlled An. stephensi and Ae. aegypti breeding in overhead storage tanks for 45 days [13]. Aqueous extract of deoiled neem (50 ppm) showed 100\% Culex quinquefasciatus larval mortality and induced prolongation of larval stages [22]. WHO recommends a dosage of 5.6-11.2 $\mathrm{mg} / \mathrm{m}^{2}$ of temephos, $1.1-1.6 \mathrm{mg} / \mathrm{m}^{2}$ of chlorpyriphos and $22.4-33.6 \mathrm{mg} / \mathrm{m}^{2}$ of fenitrothion as larvicides in mosquito con- trol programmes compared with 1.9-4.7 $\mathrm{mL} / \mathrm{m}^{2}$ for larvicidal oil [17]. In our study, $17.5 \mathrm{mg} / \mathrm{m}^{2}$ was used for temephos, $4 \mathrm{mg} /$ $\mathrm{m}^{2}$ for chlorpyriphos-methyl/fenitrothion and $5 \mathrm{~mL} / \mathrm{m}^{2}$ for neem oil.

We conclude that the efficacy of crude neem oil as a larvicide is below that of conventional larvicides. Moreover, the azadirachtin-specific action was lacking. Further studies should be done to investigate the development of resistance of mosquito larvae towards neem oil.

\section{References}

1. Africa malaria report 2003. United Nations Children's Fund \& World Health Organization, 2003 (http://www.rbm. who.int/amd2003/amr2003/ch1.htm, accessed 21 October 2004).

2. Madwar S. A preliminary note on Anopheles pharoensis in relation to malaria in Egypt. Journal of the Egyptian Medical Association, 1936, 19:616.

3. Harb M. Re-orientation of malaria control programme in Egypt, regional working group meeting on malaria control, EMRO, Alexandria, 10-11 February 1995. Alexandria, World Health Organization Regional Office for the Eastern Mediterranean, 1995 (EM/MTG/MAL/ CNT/6).

4. Bassiouny HK. Determination of epidemiological factors causing persistence of malaria, $P$. falciparum transmission in Fayoum Governorate, Egypt. In: Operational research in tropical diseases. Final report summaries 1992-2000. Cairo, World Health Organization Regional Office for the Eastern Mediterranean, 2003 (WHO-EM/TDR/004/E/G).

5. Abd-Allah SM. Comparative efficacy studies using alternative pesticide (biopesticides, insect growth regulator
(IGR) and ivermectin) on anophelinemalaria mosquitoes in Egypt. In: Operational research in tropical diseases. Final report summaries 1992-2000. Cairo, World Health Organization Regional Office for the Eastern Mediterranean, 2003 (WHO-EM/TDR/004/E/G).

6. Truman L, Bennett G, Butts W. Scientific guide to pest control operations, 3rd ed. Cleveland, Ohio, Harvest Publishing Company, 1976:207.

7. Board on Science and Technology for International Development. Neem: $A$ tree for solving global problems. National Academy Press, 1992 (http:// www.nap.edu/openbook/0309046866/ html/R1.html, accessed 21 October 2004).

8. Mulla MS, Su T. Activity and biological effects of neem products against arthropods of medical and veterinary importance. Journal of the American Mosquito Control Association, 1999, 15(2): 133-52.

9. Ley SV. Synthesis of antifeedants for insects: novel behaviour-modifying chemicals from plants. In: Chadwick DJ, Marsh $\mathrm{J}$, eds. Bioactive compounds from plants. Ciba Foundation Symposium No. 154. 
Chichester, J. Wiley and Sons, 1990:8098.

10. Prakash A, Rao J. Botanical pesticides in agriculture. New York, Lewis Publishers, 1996:35-103.

11. Mishra AK, Singh N, Sharma VP. Use of neem oil as mosquito repellent in tribal villages of Mandla district, Madhya Pradesh. Indian journal of malariology, 1995, 32(3):99-103.

12. Sharma VP, Ansari MA. Personal protection from mosquitoes (Diptera: Culicidae) by burning neem oil in kerosene. Journal of medical entomology, 1994, 31(3):505-7.

13. Nagpal BN, Srivastava A, Sharma VP. Control of mosquito breeding using wood scrapings treated with neem oil. Indian journal of malariology, 1995, 32(2):64-9.

14. Batra CP et al. Efficacy of neem oil-water emulsion against mosquito immatures. Indian journal of malariology, 1998, 35(1):15-21.

15. Dhar R et al. Effect of volatiles from neem and other natural products on gonotrophic cycle and oviposition of Anopheles stephensi and An. culicifacies (Diptera: Culicidae). Journal of medical entomology, 1996, 33(2): 195-201.

16. Manual on practical entomology in malaria. Part II: methods and techniques. Geneva, World Health Organization, 1975 (available on request from Division of Malaria and Other Parasitic Diseases, World Health Organization, 1211 Geneva, Switzerland).

17. Insecticide resistance and vector control. Seventeenth report of the WHO Expert Committee on Insecticides. Geneva, World Health Organization, 1970 (WHO Technical Report Series, No. 443).

18. Story G. Keys for the determination of Egyptian mosquitoes and their larvae. Bulletin of the Entomological Society of Egypt, 1918, 5:84-105.

19. Gillies M, De Meillon B. The anophelinae of Africa south of the Sahara (Ethiopian zoogeographical region). Johannesburg, South Africa, Publications of the South African Institute for Medical Research, 1968 (No. 54).

20. Sathyapalan $P$ et al. Laboratory evaluation of some larvicidal agents against Anopheles culicifacies in Pune. Journal of communicable diseases, 1990, 22(3): 218-22.

21. Criteria and meaning of tests for determining the susceptibility or resistance of insects to insecticides. Geneva, World Health Organization, 1976 (VBC/76.2).

22. Sagar SK, Sehgal SS. Effects of aqueous extract of deoiled neem (Azadirachta indica A juss) seed kernel and karanja (Pongamia glabra vent) seed kernel against Culex quinquefasciatus. Journal of communicable diseases, 1996, 28(4): 260-9.

المجلة الصحية لشرق المتوسط، منظمة الصحة العالمية، المجلد التاسع، العدد ع، ب...T 